The Royal Edinburgh Hospital for Sick Children, 1860-1960

Edited by DOUGLAS GUTHRIE, M.D., F.R.C.S. (ED.)

88 pages. 40 illustrations.

17s. $6 d$.

This illustrated history, describing the expansion of the work from humble beginnings and recalling the many outstanding men in medicine and surgery who have been closely associated with it, is being published to commemorate the centenary of this hospital.

\title{
The Life and Times of Sir Charles Hastings
}

Founder of the British Medical Association

By W. H. McMENEMEY, M.A., D.M., F.R.C.P., D.P.M.

528 pages. 75 illustrations.

50 s.

'Dr. McMenemey, a medical historian of distinction, has spared no trouble and pains to search out all available information and gives a vivid account of this medical pioneer and his times. He is to be congratulated on a biography of permanent value.'

\section{Shakespeare and Medicine}

British Medical Journal.

By R. R. SIMPSON, F.R.C.S. (ENG.), F.R.C.S. (ED.)

275 pages. 8 plates.

$25 s$.

'I recommend all interested in Shakespeare and his period to read this book, the product of long study and of wide reading devoted to an age which has singular fascination for the social historian as well as for the lovers of literature and drama.'

IVOR BROWN in Medical World.

\section{Essays on the First Hundred Years of Anaesthesia}

By W. STANLEY SYKES, M.B.E., M.A., M.B., B.Chir., D.P.H., D.A. 171 pages. 68 illustrations.

30 s.

These interesting and unconventional essays on the history of anaesthesia, written by an anaesthetist, are an important and valuable contribution to the subject.

\section{E. \& S. LIVINGSTONE, LTD., TEVIOT PLACE, EDINBURGH}

\section{Rare and Important Books}

Illustrating the

History OF ScIENCE

AND Medicine

Biographies AND Autograph

LETTERS OF SCIENTISTS AND

Medical Men

Catalogues on above subjects free on application

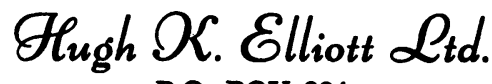
P.O. BOX 284

199 PICCADILLY

LONDON, W.1

Telephone: CUNingham 0724

Business by post or appointment only

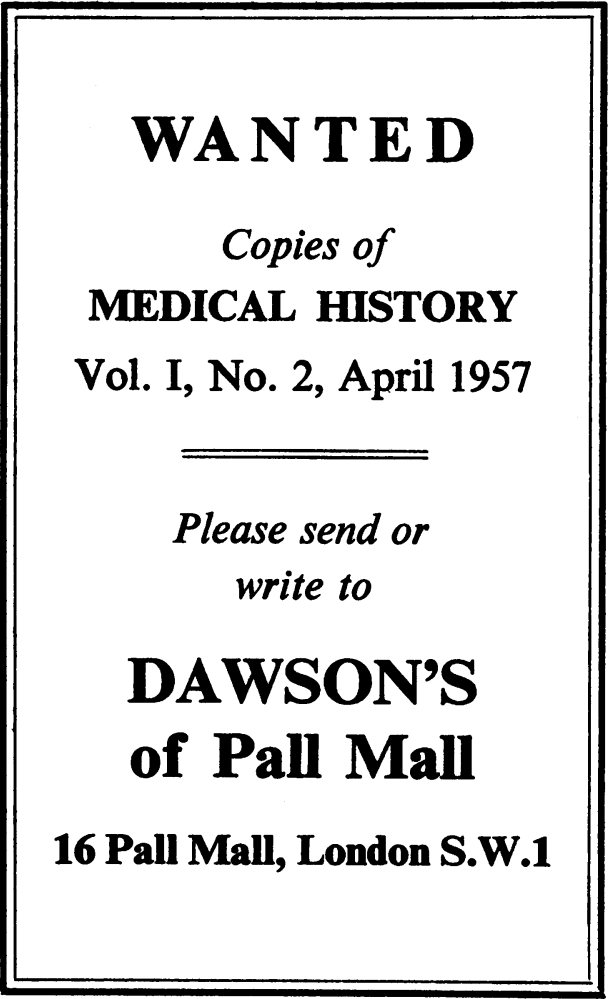




\section{S C H U M A N}

$\begin{array}{lllllllllllll} & \text { O } & R & R & A & R & \text { E } & \text { B } & \text { O } & \text { O } & K & S\end{array}$ in the

\section{History of Medicine and Science}

SPECIALIZED EXPERIENCE AND CAREFUL ATTENTION GIVEN TO THE BUILDING OF COLLECTIONS IN THE HISTORY OF MAJOR MEDICAL SPECIALITIES;

CARDFLOGY, DENTISTRY, GYNAECOLOGY, OBSTETRICS, ORTHOPAEDICS, PSYCHIATRY, PSYGHOANALYSIS, UROLOGY, ETC.

SEND US YOUR DESIDERATA

WE ARE ALWAYS GLAD TO PURCHASE ENTIRE COLLECTIONS OR SINGLE ITEMS OF MERIT

Henry Schuman Ltd, 221 I Broadway, New York 24 CABLE ADDRESS: SCHUBOOKS 


\section{THE FIRST}

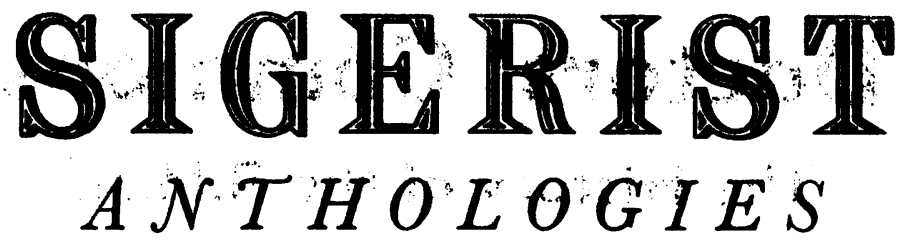

\section{H E N R Y E. S I GER IST ON THE H I S T O R Y OF MEDICINE edited by Félix Marti-Ibatiez, M.P. foreword by \\ John F. Fulton, M.D.}

In twenty-seven carefully selected essays and lectures, collected in this anthology for the first time in English, Dr. Sigerist provides an illuminating view of the men and the events that have shaped the present and will affect the future of medicine and civilization. The brilliant and stimulating writings contained in this long-awaited anthology are the essence of the Sigerist ideas, concepts, and theories on the history of medicine. Whether focusing .on Hippocrates, Paracelsus in the Light of Four Hundred Yeârs, The Physician's Profession Through the Ages, Bedside Manners in the Middle Ages, or The Philosophy of Hygiene, Sigerist reveals the wit, scholarship, and originality that made him one of the greatest medical historians of our time.

336 pages Cloth Bound $\$ 6.75$

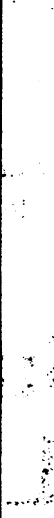

\section{H E N R Y E. S I GER IS T $O N T H E$ S O G I O L G Y OF MED I C I NE edited by Milton I. Roemer, M.D. foreword by James M. Mackintosh, M.D.} The scope and depth of Sigerist's theories on the sociology of medicine have never been more clearly shown than in this first Englishlanguage anthology of his medicosociological writings. These thirtyone selected essays are truly representative of Sigerist as humanist and social reformer. Because of Sigerist's originality and scholarship, these writings remain fresh, powetiful and deserving of a place with the great medico-historical literature of all time. All of these essays, whether they deal with War and Medicine, The Special Position of the Sick, Socialized Medicine, or Gurrent Unrest in the Medical World, reflect the mind and heart of a great man who strove to turn social philosophy into constructive social action.

406 pages Cloth Bound \$6.75

These two handsome volumes can be ordered as a set for only $\$ 10$

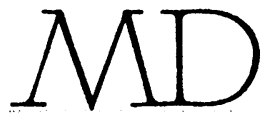

PUBLICATIONS, INC. · 30 E. 60th Street, New York 22, N.Y. 


\title{
Doctors' Commons The History of the B.M.A.
}

\author{
PAUl VAUGHAN
}

'Clear, vigorous and thoroughly readable survey.' JEAN HOWARD, Spectator. 'Mr. Vaughan has performed a public service with a book that explains clearly that the ethics of a doctor are no mumbo-jumbo of a secret society, but expressly designed to help his fellow man.'Weekly Scotsman. 18 s.

\section{The Surgeon's Log}

\section{J. JOHNSTON ABRAHAM}

Few travel books have had such well-deserved success as J. Johnston Abraham's account of his experiences as ship's surgeon on a deep-sea trading steamer all over the world. St. John Ervine reviewing the thirtieth edition wrote: 'It's kept me from my work for an entire day. . . . Mr. Johnston Abraham is a born writer.'

A re-issue. 18s.

\section{Surgeon Compassionate}

FRIEDA SANDWITH

Published by Peter Davies Ltd.

The story of Dr. William Marsden, M.D., M.R.C.s. A detailed and vivid biography of the founder of the Royal Free and the Royal Marsden Hospitals, written by his great-grand-daughter.

Illustrated, 21 s.

HEINEMANN 